\title{
Ograniczanie występowania zjawiska bezdomności na przykładzie programu Housing-First
}

\author{
Dominika Cendrowicz*
}

\begin{abstract}
Streszczenie: Podstawowym celem opracowania jest przybliżenie założeń stworzonego w Stanach Zjednoczonych przez dr. S. Tsemberisa z organizacji „Pathways to housing” programu o nazwie Housing First, którego założeniem jest pomoc osobom bezdomnym w wyjściu ze stanu bezdomności, oraz sformułowanie wniosków co do możliwości jego stosowania przez krajową administrację publiczną przy uwzględnieniu istniejących w Polsce uwarunkowań prawnych i organizacyjnych. Wysoka skuteczność programu Housing First w pomocy świadczonej osobom bezdomnym spowodowała bowiem, że w Europie Zachodniej został przeprowadzony w latach 2011-2013 program pilotażowy pod nazwą Housing First Europe. Program ten przeprowadzono w Amsterdamie, Budapeszcie, Kopenhadze, Glasgow i w Lizbonie. Kolejnym celem opracowania jest porównanie założeń programu Housing First z rekomendowanym w Unii Europejskiej podejściem housing-led. W opracowaniu wykorzystano metodę empiryczną oraz teoretyczno-prawną.
\end{abstract}

Słowa kluczowe: bezdomność, osoby bezdomne, program Housing First, podejście housing-led.

\section{Wprowadzenie}

Bezdomność jest jedną z najskrajniejszych i najbrutalniejszych form wykluczenia społecznego [Mędrzycki, 2013; Olech, 2013]. Jak wskazują zapisy jednego z kluczowych dokumentów w zakresie walki z ubóstwem: "koreluje ze skrajnym ubóstwem, bezrobociem, niską intensywnością pracy, zatrudnieniem w szarej strefie, utratą zdrowia i zagrożeniem życia, problemami zdrowia psychicznego, niemożliwością funkcjonowania w rodzinie i społeczeństwie" [Krajowy program przeciwdziałania ubóstwu, 2014]. Jest szczególnie bolesnym zjawiskiem, gdyż człowiek, którego ono dotyczy, funkcjonuje bez dachu nad głową i bez przestrzeni, w której mógłby schronić się przed trudnymi życiowymi sytuacjami [Moraczewska, 2013, s. 113]. Jednocześnie zjawisko bezdomności umyka powszechnym badaniom społecznym dotyczącym ubóstwa, wykluczenia społecz- nego, gospodarstw domowych czy też bezrobocia [Krajowy program przeciwdziałania ubóstwu, 2014]. Ludziom, którzy mają dom, trudno zrozumieć bezdomnych, a przecież osoby bezdomne można dziś spotkać na ulicach każdego europejskiego miasta [Moraczewska, 2013, s. 113]. Liczba osób bezdomnych wzrasta bowiem z roku na rok. Według danych z 2013 r. w Rosji żyło 5 milionów osób bezdomnych (czyli 3,5\% rosyjskiego społeczeństwa), z czego 1 milion stanowiły dzieci [Homeless World Cup Foundation, 2015]. We Francji w 2012 r. co najmniej 141,5 tys. osób nie miało dachu nad głową. W tym samym okresie w Niemczech 284 tys. osób nie miało

\footnotetext{
* Dominika Cendrowicz

Zakład Nauki Administracji Instytut Nauk Administracyjnych Wydział Prawa, Administracji i Ekonomii Uniwersytet Wrocławski ul. Uniwersytecka 22/26, 50-145 Wrocław e-mail: dominika.cendrowicz@uwr.edu.pl
} 
gdzie mieszkać, a w Hiszpanii około 40 tys. osób było bezdomnych [ibidem; por. Schulz, 2011, s. 57-71].

Obecnie problem bezdomności w danym państwie nie dotyczy już tylko i wyłącznie jego obywateli. W wielu miastach europejskich osoby bezdomne lub zagrożone bezdomnością to także obcokrajowcy [Jabłecka, 2017]. Tak jest na przykład w Londynie, gdzie znaczna część mieszkających na ulicach osób pochodzi z Europy Środkowej i Wschodniej. Zjawisko bezdomności wśród migrantów zarobkowych dotyka w zatrważającej mierze także obywateli polskich. Wśród londyńskich bezdomnych największą grupę obcokrajowców stanowią Polacy [Garapich, 2016, s. 124], a co druga osoba bezdomna w Berlinie pochodzi z Polski [Goryńska-Bittner, 2010]. Skalę występowania bezdomności nasila dodatkowo pogłębiający się kryzys uchodźczy [Schulz, 2014, s. 15]. Również w Polsce bezdomność dotyczy coraz większej liczby osób (na podstawie przeprowadzonego w nocy z 8 na 9 lutego 2017 r. ogólnopolskiego badania liczby osób bezdomnych ustalono, że w dacie jego przeprowadzenia w całym kraju było 33,4 tys. osób bezdomnych, z czego 83,55\% stanowili mężczyźni) [MRPiPS, 2017].

Mimo nasilającej się w warunkach polskich skali bezdomności, nie znajduje ona od wielu lat odpowiednich rozwiązań prawnych [Mędrzycki, 2016b, s. 35]. Co prawda formy przeciwdziałania bezdomności znajdują swoje uregulowanie $w$ wielu aktach prawnych, rozpoczynając od Konstytucji RP1, a skończywszy na ustawie z dnia 12 marca 2004 r. o pomocy społecznej², poprzez akty prawa międzynarodowego oraz różnego rodzaju rezolucje, deklaracje, strategie, czy wytyczne i programy Unii Europejskiej (m.in. strategia lizbońska, rezolucja Parlamentu Europejskiego z dnia 16 stycznia 2014 r.

Dz.U. Nr 78 poz. 483 z późn. zm, dalej: Konstytucja RP. T.j. Dz.U. z 2017 r. poz. 1769 z późn. zm, dalej: u.p.s. w sprawie strategii Unii Europejskiej na rzecz przeciwdziałania bezdomności, deklaracja Parlamentu Europejskiego z 2007 r. o likwidacji bezdomności ulicznej) [Schulz, 2011b, s. 11 i nast.], to jednak - jak wskazuje R. Mędrzycki - polska polityka społeczna w omawianym zakresie nie jest spójna, regulacja prawna odnosząca się do pomocy osobom bezdomnym jest rozproszona w wielu aktach prawnych [Mędrzycki, 2013, s. 186], a podstawową formą pomocy adresowaną do osób bezdomnych pozostaje wciąż udzielanie im tymczasowego schronienia w placówkach instytucjonalnego wsparcia, do których w aktualnym stanie prawnym należą schroniska, noclegownie i ogrzewalnie ${ }^{3}$.

\section{Modele pomocy osobom bezdomnym}

Schronienie w schronisku, noclegowni i ogrzewalni stanowi wyłącznie tymczasową formę pomocy 4 . Ponadto jest to pomoc realizująca założenia tzw. modelu drabinkowego,

\footnotetext{
W obecnym stanie prawnym udzielanie schronienia regulują przepisy u.p.s. w art. 48 i 48a. W świetle przepisów tej ustawy udzielanie schronienia osobom potrzebującym stanowi obowiązkowe zadanie własne gminy (art. 17 ust. 1 pkt 3 u.p.s.)

4 Schronienie nie stanowi formy pomocy, która sprzyjałaby wychodzeniu ludzi z bezdomności. Pomoc w formie schronienia stanowi pomoc o doraźnym charakterze, która sprowadza się do zapewnienia człowiekowi niezbędnej ochrony przed niekorzystnymi czynnikami atmosferycznymi. Udzielenie schronienia nie oznacza zapewnienia osobie stałego miejsca zamieszkania. Celem tej formy pomocy jest jedynie umożliwienie potrzebującej go osobie, z uwagi na utratę dotychczasowego miejsca zamieszkania (pobytu), tymczasowego schronienia. O tym, że udzielenie schronienia w placówkach instytucjonalnego wsparcia, jak schroniska, noclegownie i ogrzewalnie nie ma charakteru stałego przesądzają użyte w u.p.s. zwroty wskazująca na tymczasowość tej formy pomocy [Nitecki, 2013, s. 385]. Wskazuje się na to również w orzecznictwie sądów administracyjnych. To, że schronienie nie prowadzi do rozwiązania problemu bezdomności nie oznacza jednak, że nie należy doceniać tej formy pomocy. Jej praktyczny wymiar aktualizuje się w okresach zimowych, kiedy to na skutek niskich temperatur udzielenie schronienia niejednokrotnie przesądza o uratowaniu życia człowieka (szerzej na temat form pomocy administracji publicznej na rzecz osób bezdomnych: Sierpowska, 2016, s. 29-51).
} 
w myśl którego osoby bezdomne na swojej drodze prowadzącej do ich pełnego usamodzielnienia powinny przejść kolejno przez wszystkie etapy prowadzące do osiągnięcia tego celu. Model drabinkowy opiera się bowiem na założeniu, zgodnie z którym najpierw powinny zostać rozwiązane problemy socjalne, zdrowotne i psychologiczne osoby bezdomnej oraz związane z jej aktywnością zawodową (a raczej jej brakiem). Dopiero po uporaniu się z nimi osoba bezdomna ma możliwość uzyskania stałego zamieszkania poza placówką pomocową [Browarczyk, Stenka, 2012, s. 178, 181-182]. W modelu drabinkowym uzyskanie mieszkania jawi się więc nie jako forma realizacji przysługującego każdemu człowiekowi prawa do mieszkalnia, ale jako pewna nagroda, na którą można zasłużyć dopiero po przejściu wszystkich szczebli drabiny prowadzącej do życiowego usamodzielnienia się.

Obok drabinkowego modelu pomocy wyróżnia się jeszcze inne modele pomocy osobom bezdomnym. Należą do nich modele: mieszkaniowy, palety i wspólnotowy. W modelu mieszkaniowym rozwiązywanie problemu bezdomności powinno w pierwszej kolejności opierać się na zapewnieniu mieszkań, a następnie na świadczeniu w nich, a nie w placówkach instytucjonalnych, pomocy osobom bezdomnym. Model palety zakłada z kolei, że osoby doświadczające bezdomności oraz zagrożone nią mogą w zależności od swoich potrzeb - bezpośrednio zgłosić się po pomoc w zakresie, jakiego potrzebują. W modelu tym osoba bezdomna ma możliwość skorzystania z pomocy świadczonej na poszczególnych jego poziomach [ibidem, s. 180-181]. Ostatni już z wyróżnionych modeli - model wspólnotowy - zakłada zaś, że osoby bezdomne, jak i osoby zagrożone bezdomnością, mogą uzyskać wsparcie i pomoc w placówkach prowadzonych przez podmioty spoza systemu administracji publicznej [Sierpowska, 2016, s. 183-184].
Z przedstawionych modeli na znaczeniu w ostatnim czasie zyskują te z nich, które swoją filozofię opierają na dostępie do mieszkań lub na mieszkalnictwie. $\mathrm{Na}$ kwestii dostępu do mieszkań oparta została idea zyskującego na popularności programu Housing First [szerzej: Atherton, McNaughton, 2008, s. 289-303; NAEH, 2016; Tsemberis, 2010]. Program ten, a także wypracowane na jego bazie podejście określane mianem housing-led stanowią obecnie przedmiot szczególnego zainteresowania ze strony Unii Europejskiej, która w swoich działaniach stawia sobie za cel walkę z bezdomnością i likwidację zjawiska bezdomności ulicznej. W dalszej części artykułu omówiona została więc idea podejścia housing-first, od którego rozpoczęła się popularność programów opartych na dostępie do mieszkań, dokonane zostało porównanie podejść housing-first i housingled oraz podjęta została próba sformułowania wniosków co do możliwości stosowania w Polsce programów opartych o ich założenia [por. Pleace, Bretherton, 2013].

\section{Model pomocy osobom bezdomnym na przykładzie programu Housing First}

Idea programu Housing First i jego podstawowe założenia zostały sformułowane przez dr. S. Tsemberisa w latach dziewięćdziesiątych ubiegłego wieku w ramach działającej w Nowym Jorku organizacji "Pathways to Housing". Początkowo program ten miał na celu pomoc osobom bezdomnym mającym problemy ze zdrowiem psychicznym, z których znaczna część doświadczyła już pobytu w szpitalach psychiatrycznych. Z czasem krąg jego docelowych beneficjentów objął osoby długotrwale przebywające w schroniskach dla bezdomnych oraz znajdujące się w stanie zagrożenia bezdomnością, do których należały osoby opuszczające szpitale psychiatryczne lub więzienia [Pleace, 2016 , s. 16]. Obecnie jego adresatami są nie 
tylko osoby bezdomne borykające się z problemami ze zdrowiem psychicznym, ale również uzależnione od narkotyków, alkoholu, a także cierpiące na depresję, za wyjątkiem osób chorych i niepełnosprawnych. Są nimi również osoby długotrwale bezdomne lub takie, które co jakiś czas w tym stanie się znajdują i którym często najbardziej brakuje tzw. wsparcia społecznego, czyli pomocy przyjaciół lub rodziny. W Stanach Zjednoczonych i Kanadzie adresatami programu Housing First są także bezdomne rodziny i bezdomna młodzież [ibidem, s. 15].

\section{Prawo do mieszkania jako podstawowa zasada programu Housing First}

Istota programu Housing First opiera się na stopniowym wycofywaniu schronisk dla osób bezdomnych, na rzecz upowszechniania stałych form zamieszkania [Rozwiązywanie problemu bezdomności, 2011]. Stąd też w programie Housing First w pierwszej kolejności proponuje się osobie przeniesienie się do samodzielnego mieszkania, które w miarę posiadanych przez nią możliwości finansowych i możliwości finansowych organizatorów programu spełnia jej oczekiwania, a dopiero później proponuje się jej rozpoczęcie pracy nad problemami, które legły u podstaw znalezienia się przez nią w stanie bezdomności. Program Housing First wprowadza tym samym odwróconą w stosunku do modelu drabinkowego kolejność udzielania pomocy osobie jej potrzebującej [Wygnańska, 2015, s. 3].

A zatem podstawową zasadą programu Housing First jest uznanie, że mieszkanie stanowi prawo każdego człowieka [por. Płoszka, 2015]. Zgodnie z tą zasadą mieszkanie jest jednym z podstawowych dóbr egzystencjonalnych, zaspokaja elementarne potrzeby bytowe, daje poczucie bezpieczeństwa, kształtuje materialne i społeczne warunki życia człowieka [Sierpowska, 2010, s. 280].
Warto w tym kontekście zauważyć, że prawo do mieszkania znajduje obecnie uznanie w wielu aktach prawa międzynarodowego [szerzej: Kenna et al., 2016]. Podstawowym dokumentem pozostaje $w$ tym zakresie Powszechna Deklaracja Praw Człowieka5, która w art. 25 stanowi, że każdy człowiek ma prawo do poziomu życia zapewniającego zdrowie i dobrobyt jemu i jego rodzinie, włączając w to wyżywienie, odzież, mieszkanie, opiekę lekarską i niezbędne świadczenia socjalne oraz prawo do zabezpieczenia na wypadek bezrobocia, choroby, niezdolności do pracy, wdowieństwa, starości lub utraty środków do życia w sposób od niego niezależny. Kolejnym aktem prawa międzynarodowego o istotnym znaczeniu w omawianym zakresie jest Międzynarodowy Pakt Praw Gospodarczych, Społecznych i Kulturalnych6, który w art. 11 zobowiązuje państwa będące jego stronami do uznania prawa każdego człowieka do odpowiedniego poziomu życia, w szczególności w zakresie wyżywienia, odzieży i mieszkania, oraz prawa do stałego polepszania warunków bytowych. Oprócz tego należy wskazać na art. 7 i 34 Karty Praw Podstawowych Unii Europejskiej”, art. 31 Europejskiej Karty Społecznej ${ }^{8}$ oraz na rezolucję Parlamentu Europejskiego w sprawie mieszkalnictwa i polityki regionalnej przyjętą 10 lipca 2007 r., a w dalszej kolejności na deklarację Habitat ${ }^{9}{ }^{9}$ Drugiej Konferencji Organizacji Narodów Zjednoczonych w sprawie Osiedli Ludzkich, której sygnatariusze zobowiązali się działać w „kierunku zwiększenia podaży dostępnych cenowo obiektów mieszkalnych poprzez umożliwienie spraw-

\footnotetext{
Dz.U.z 1969 r. nr 25 poz. 187

Dz.U. z 1977 r. nr 38 poz. 169.

Dz.Urz. UE C 303 z dnia 14 grudnia 2007 r., s. 1 ze sprost.

Dz.U.z 1999 r. nr 8, poz. 67.

W dniach 3-14 czerwca 1996 r. w Stambule obradowała Druga Konferencja Narodów Zjednoczonych poświęcona Siedzibom Ludzkim Habitat II. Podczas konferencji zajmowano się problemami bezdomności, bezrobocia, infrastrukturą miejską. Efektem Konferencji było uchwalenie tzw. Deklaracji Habitat II.
} 
nego i odpowiedzialnego, z punktu widzenia społecznego i środowiskowego, działania rynków, poprawienie dostępu do terenów i kredytu oraz pomaganie tym, którzy nie są w stanie korzystać z rynku mieszkaniowego".

W prawie krajowym do problematyki prawa człowieka do mieszkania odnosi się art. 75 Konstytucji RP, zgodnie z którym „Władze publiczne prowadzą politykę sprzyjającą zaspokojeniu potrzeb mieszkaniowych, w szczególności przeciwdziałają bezdomności, wspierają rozwój budownictwa socjalnego oraz popierają działania obywateli zmierzające do uzyskania własnego mieszkania". Zakres ochrony praw lokatorów określa natomiast ustawa z 21 czerwca 2001 r. o ochronie praw lokatorów, mieszkaniowym zasobie gminy i o zmianie Kodeksu cywilnego $^{10}$. W literaturze podkreśla się, że art. 75 Konstytucji RP nie stanowi samoistnej podstawy do żądania mieszkania od władz publicznych [Sierpowska, 2010, s. 285] i nie może być źródłem roszczenia przeciwko państwu o jego dostarczenie [Skrzydło, 2007, s. 74]. Z jednej więc strony Konstytucja RP nie przyznaje nikomu roszczenia wobec państwa o dostarczenie lokalu mieszkalnego, z drugiej jednak strony konkretyzuje obowiązki państwa w tym względzie, pozostawiając państwu swobodę wyboru środków realizacji polityki mieszkaniowej [Mikłaszewicz, 2016, s. 1713; wyrok TK, 2003 r., SK 28/03; wyrok TK, 2005 r., K 42/02].

Nawiązując do obowiązującego w krajowym systemie prawnym rozumienia prawa do mieszkania, należy zauważyć, że S. Tsemberis opisując zasadę "mieszkanie jako prawo" przywołuje artykuł 25 Powszechnej Deklaracji Praw Człowieka Organizacji Narodów Zjednoczonych [Mieszkanie jako prawo człowieka, 2015]. O czym była bowiem mowa, w programie Housing First mieszkanie nie jest traktowane jako przynęta mająca

10 T.j. Dz. U. z 2016 r. poz. 1610 z późn. zm., dalej: ustawa o ochronie praw lokatorów i mieszkaniowym zasobie gminy. skłonić osobę do rozpoczęcia leczenia. Jest oferowane jako to, do czego ma ona prawo [ibidem]. Także choć w krajowym systemie prawnym jednostka nie posiada roszczenia o dostarczenie jej mieszkania, nie stoi to w sprzeczności z ideą programu oraz przyjętym w nim rozumieniem mieszkania jako prawa każdego człowieka, a zwłaszcza osoby bezdomnej. Uzasadnia ono również przyjętą w ramach programu odwróconą kolejność udzielania pomocy, zgodnie z którą na mieszkanie nie trzeba zasłużyć. Udostępnienie mieszkania stanowi bowiem punkt wyjścia dla udzielania skutecznej pomocy dla bezdomnych w procesie ich integracji ze społeczeństwem [Przymeński, 2014, s. 241].

\section{Pozostałe zasady programu Housing First}

Kolejne zasady programu Housing First to szacunek, serdeczność i współodczuwanie dla wszystkich osób będących jego beneficjentami [Wygnańska, 2015, s. 16 i nast.], reguła wykorzystywania do programu mieszkań, które nie znajdują się w bliskim sąsiedztwie, co stwarza osobom korzystającym z programu szansę na integrację ze społecznością lokalną i zapobiega ich stygmatyzacji, oddzielenie mieszkania od usług wspierających, uznanie, że podstawą wyboru mieszkania, a także zakresu i intensywności usług wspierających jest samodzielna decyzja osoby uczestniczącej w programie, orientacja na wyzdrowienie, zasada redukcji szkód [ibidem, s. 50] oraz uznanie, że praca z beneficjentami programu powinna trwać tak długo, jak długo wymagają tego ich potrzeby. Treść ostatniej z wymienionych zasad została dobrze wyjaśniona w przewodniku „Housing First Europe" z 2016 r., w którym podkreślono, że dla osób, które przez wiele lat nie posiadały dachu nad głową, sam fakt posiadania mieszkania może być odczuwany jako nienaturalna sytuacja, do której trudno jest im się przyzwyczaić. Trzeba bowiem zdać sobie sprawę, 
że osoby bezdomne przebywają latami w schroniskach lub w innych placówkach przeznaczonych dla osób bezdomnych, bądź też żyją po prostu na ulicy. Toteż konieczność udzielania im niezbędnego wsparcia - po to, aby mogły nauczyć się żyć samodzielnie i radzić sobie w społeczeństwie - trwa niejednokrotnie dłużej, aniżeli sam proces uzyskania mieszkania [Pleace, 2016, s. 37], przy czym korzystanie z omawianego wsparcia odbywa się zawsze na zasadzie dobrowolności [Dębski, 2014, s. 120 i nast.].

\section{Zakres pomocy udzielanej w ramach programu Housing First}

Do podstawowych założeń programu Housing First należy zatem uznanie, zgodnie z hierarchią potrzeb Maslowa [Maslow, 2007], że poczucie bezpieczeństwa, wygody, spokoju, wolności od strachu jest jedną z najważniejszych potrzeb w życiu człowieka i jako takie ustępuje ono jedynie miejsca potrzebom fizjologicznym [Dębski, 2014, s. 120 i nast.]. Zakres udzielanej w ramach Housing First pomocy obejmuje jednak nie tylko zapewnienie mieszkania, ale również pomoc polegającą na świadczeniu usług pozwalających na utrzymanie się w nim. Toteż świadczone w ramach Housing First usługi obejmują w szczególności pomoc w prawidłowym gospodarowaniu finansami przez osobę, której zapewniono mieszkanie. Uczestnik programu Housing First jest bowiem obowiązany do przeznaczania 30\% swoich dochodów na opłatę czynszu. Pozostałą kwotą może on swobodnie dysponować. Jednak osoby borykające się z długoletnią bezdomnością mogą mieć problemy z prawidłowym rozdziałem posiadanych środków finansowych.

W ramach Housing First świadczy się także pomoc w integracji ze społeczeństwem, a także formę pomocy, którą określilibyśmy mianem monitorowania sytuacji mieszkaniowej beneficjenta programu. Ta forma pomocy polega m.in. na sprawdzeniu warunków panujących w mieszkaniu, które będzie wynajmowane przez osobę uczestniczącą w programie. W dalszej kolejności pomoc ta obejmuje, przykładowo, wyjaśnienie uczestnikowi programu praw i obowiązków wynikających z umowy najmu, która jest preferowaną formą wejścia w posiadanie dachu nad głową w ramach Housing First. Pomoc w ramach Housing First może także obejmować wsparcie $w$ radzeniu sobie z samotnością oraz udzielanie innych form pomocy w sytuacji, w której zaistnieje konieczność ich świadczenia (zalicza się do nich takie formy jak chociażby wytłumaczenie, jak należy obsługiwać kuchenkę do gotowania, pralkę, jak korzystać z pilota do TV czy ze zmywarki do naczyń) [Wygnańska, 2015, s. 107 i nast.; Pleace, 2016, s. 42].

\section{Podejście housing-first a housing-led}

W kontekście przyjętego tematu publikacji zauważenia wymaga, że w Europie strategie przeciwdziałania bezdomności tradycyjnie skupiają się na podejściu housing-led, które wykształciło się ze stworzonego w Stanach Zjednoczonych podejścia housing-first [zob.: Housing-led policy, 2011]. Wobec tego porównania wymagają podejścia housingfirst i housing-led [szerzej: Allen, 2016, s. 159166]. Również z tej przyczyny, że bywają one dość często ze sobą mylone, co - jak zauważa J. Wygnańska - jest błędem, ponieważ housing-led to podejście skoncentrowane na kwestii mieszkalnictwa i o mieszkalnictwo oparte. Housing-first zajmuje się natomiast w pierwszej kolejności dostępem do mieszkań i traktuje mieszkanie jako prawo człowieka11. Ponadto housing-first było pierwsze. Tymczasem termin housing-led został użyty po raz pierwszy na forum Europejskiej Konferencji Konsensusu w sprawie Bezdomno-

1 Dz.Urz. UE z dnia 19 sierpnia 2014 r., C 271/36 
ści, która odbyła się w dniach 9 i 10 grudnia 2010 r. w Brukseli, w trakcie której rekomendowano, by w Europie podejście housing-first wprowadzane było z uwzględnieniem jego europejskiego kontekstu. Jury Konferencji rekomendowało wówczas używanie podejścia housing-led „jako szerszego (w porównaniu do Housing First - D.C.) i bardziej zróżnicowanego" [za: Busch-Geertsema, 2016, s. 10].

Rekomendowane przez Jury Konferencji Konsensusu podejście housing-led szybko zyskało popularność w Europie i znalazło swój wyraz w dokumentach stanowionych przez Unię Europejską. Tytułem przykładu można wskazać na przyjętą w dniu 14 września 2011 r. przez Parlament Europejski rezolucję wzywającą Unię Europejską do przyjęcia strategii na rzecz zwalczania bezdomności, w której zaapelowano o to, aby $\mathrm{w}$ ramach rozdziału dotyczącego innowacji społecznych europejskiej platformy w zakresie walki z ubóstwem i wykluczeniem społecznym skoncentrować się przede wszystkim na podejściach opierających się na mieszkalnictwie, co pozwoli na zebranie przekonujących danych w zakresie skutecznego łączenia wsparcia na mieszkalnictwo z pozostałymi formami pomocy dla byłych bezdomnych oraz gromadzenie informacji opartych na doświadczeniach praktycznych i tworzeniu rozwiązań politycznych ${ }^{12}$.

A zatem w świetle założeń housing-led polityka mieszkalna odgrywa istotną rolę $\mathrm{w}$ rozwiązywaniu problemu bezdomności [Dz.Urz. UE z dnia 19 sierpnia 2014 r., C 271/36]. Podstawowym narzędziem wspierania wychodzenia z bezdomności w ramach tego podejścia nie są jednak tylko programy o charakterze mieszkaniowym, ale także usługi wspierające zorientowane na potrzeby byłych bezdomnych oraz zagrożonych bezdomnością [Wygnańska, 2013]. Według założeń housingled osoby bezdomne przechodzą przez etapy

12 W listopadzie 2011 r. Europejskie Obserwatorium na Rzecz Przeciwdziałania Bezdomności (FEANTSA) opublikowało raport zatytułowany "Housing-led policy approaches: Social innovation to end homelessness in Europe". tymczasowego zakwaterowania przed udostępnieniem im stałego mieszkania, a więc inaczej niż w housing first, które oferuje bezpośredni dostęp do stałego zakwaterowania przyjmując, że mieszkanie stanowi prawo człowieka, które nie jest uzależnione od jego zaangażowania w leczenie. Mimo tych zasadniczych różnic między omawianymi podejściami są one jednak równie popularne, gdy idzie o rozwiązywanie problemu bezdomności. Tytułem przykładu można wskazać, że wyrazem uznania podejścia housing-first w Europie dla rozwiązywania problemu bezdomności było przeprowadzenie w latach 2011-2013 w pięciu europejskich miastach (Amsterdam, Budapeszt, Kopenhaga, Glasgow i Lizbona) projektu pod nazwą „Housing First Europe"13.

\section{Podsumowanie}

W konkluzji należy uznać, że idea housingfirst może być odnoszona do oryginalnego programu, jego różnych wersji oraz do krajowych polityk społecznych i strategii dotyczących bezdomności [Wygnańska, 2015, s. 147]. Każda idea czy też innowacja w zakresie pomocy osobom bezdomnym musi odnosić się jednak do istniejących w danym kraju uwarunkowań prawnych, finansowych i organizacyjnych [Mędrzycki, 2016a, s. 63]. Odnosząc ją zatem do warunków krajowych należy zauważyć, że:

1. Formy $\mathrm{i}$ instrumenty udzielania pomocy mieszkaniowej przez administrację publiczną w Polsce są zróżnicowane i zależą nie tylko od sytuacji osób, które się o nią starają, ale przede wszystkich od organizacyjnych i finansowych możliwości gmin, które tej pomocy udzielają [Przymeński, 2014, s. 242]. Wśród obowiązkowych form pomocy świadczonych przez administrację na rzecz osób bez-

\footnotetext{
13 Projekt ten finansowany był przez Komisję Europejską. Jednak to właśnie podejście housing-led zostało rekomendowane przez Jury Europejskiej Konwencji Konsensusu.
} 
domnych nie znajdują się w aktualnym stanie prawnym programy oparte o formułę housing-first;

2. Liczba mieszkań socjalnych ${ }^{14}$, które mogłyby stać się przedmiotem najmu w ramach housing-first wynosiła w 2015 r. 91706 lokali, w tym 5595 lokali niezamieszkałych [GUS, 2015]. Biorąc pod uwagę skalę bezdomności w Polsce, jest to liczba niewystarczająca. Toteż, z uwagi na istniejącą liczbę lokali socjalnych, bazy lokalowej dla potrzeb realizacji programu housing-first w Polsce można byłoby poszukiwać np. na rynku prywatnym. $W$ realiach polskich nie jest jednak możliwe, aby bazę lokalową dla programu housing-first stanowić mogły wyłącznie mieszkania prywatne. Kolejną alternatywę mogłyby więc stanowić mieszkania chronione ${ }^{15}$ oraz baza mieszkaniowa tworzona na potrzeby Krajowego Zasobu Nie-

${ }^{14}$ Definicja lokalu socjalnego znajduje się w art. 2 ust. 1 pkt 5 ustawy o ochronie praw lokatorów, mieszkaniowym zasobie gminy. Lokalem socjalnym, zgodnie z tą definicją, jest lokal nadający się do zamieszkania ze względu na wyposażenie i stan techniczny, którego powierzchnia pokoi przypadająca na członka gospodarstwa domowego najemcy nie może być mniejsza niż $5 \mathrm{~m}^{2}$, a w wypadku jednoosobowego gospodarstwa domowego $10 \mathrm{~m}^{2}$, przy czym lokal ten może być o obniżonym standardzie.

${ }^{5}$ Definicja mieszkania chronionego znajduje się w art. 53 ust. 2 u.p.s., zgodnie z którym "Mieszkanie chronione jest formą pomocy społecznej przygotowującą osoby tam przebywające, pod opieką specjalistów, do prowadzenia samodzielnego życia lub zastępującą pobyt w placówce zapewniającej całodobową opiekę. Mieszkanie chronione zapewnia warunki samodzielnego funkcjonowania w środowisku, w integracji ze społecznością lokalną." Rodzaj i zakres udzielanego w mieszkaniach chronionych wsparcia określa rozporządzenie Ministra Rodziny, Pracy i Polityki Społecznej z dnia 26 kwietnia 2018 r. w sprawie mieszkań chronionych (Dz.U. z 2018 r., poz. 822). Zgodnie z § 6 ust. 1 tego rozporządzenia "minimalna powierzchnia użytkowa przypadająca dla jednej osoby korzystającej ze wsparcia w mieszkaniu chronionym nie może być mniejsza niż $12 \mathrm{~m}^{2}$, przy czym liczba osób w mieszkaniu chronionym nie może być wyższa niż 7". Rozporządzenie określa jakie warunki powinny spełniać mieszkania chronione (np. brak barier architektonicznych dla osób niepełnosprawnych) i w jaki sprzęt powinny być one wyposażone (np. telewizor lub komputer, pralka automatyczna, chłodziarka). Ponadto określa ono zakres usług świadczonych w mieszkaniach chronionych. Powyższe wymogi określone w stosunku do mieszkań chronionych ruchomości. Ustawa z dnia 27 lipca 2017 r. o Krajowym Zasobie Nieruchomości ${ }^{16}$ wprowadziła jednak do ustawy o ochronie praw lokatorów instytucję najmu instytucjonalnego lokali należących do tego zasobu. Instytucja ta zaś wiąże się z możliwością eksmisji najemcy "na bruk”. Do umowy najmu instytucjonalnego lokalu załącza się bowiem oświadczenie najemcy $w$ formie aktu notarialnego, w którym najemca zobowiązuje się do poddania się egzekucji i do opróżnienia i wydania lokalu używanego na podstawie umowy najmu instytucjonalnego lokalu w terminie wskazanym w żądaniu opróżnienia lokalu oraz oświadcza, że przyjmuje do wiadomości, że w razie konieczności wykonania powyższego zobowiązania prawo do lokalu socjalnego ani pomieszczenia tymczasowego mu nie przysługuje ${ }^{17}$;

3. Oprócz istniejących w Polsce deficytów mieszkaniowych istnieją też ich deficyty jakościowe ${ }^{18}$.

Powyższe czynniki powodują, że metoda housing-first nie jest łatwa do stosowania w warunkach polskich i znajduje swoich zwolenników, jak i przeciwników. Jedni wskazują, że posiadanie bezpiecznego miejsca jest podstawą świadczenia jakichkolwiek form wsparcia osobom bezdomnym, drudzy podkreślają, że metoda ta jest zbyt kosztowna [Dębski, 2014, s. 123], a jej odniesienie do polskich realiów nie jest łatwe. Bez wątpienia metoda housing-first ma charakter innowacyjny i nowatorski oraz wykazuje się wysoką skutecznością w krajach Europy Zachodniej i w Stanach Zjednoczonych, gdy idzie o zakładane przez nią cele. W Polsce, odwołując się do słowa wstępnego Rzecznika Praw

poddają w wątpliwość ich stosowanie do koncepcji programu Housing First" [podaję za: Wygnańska, 2015, s. 86].

16 Dz.U. z 2017 r. poz. 1529.

17 Stanowi o tym art. $19 f$ ust. 3 ustawy o ochronie praw lokatorów, mieszkaniowym zasobie gminy.

8 Załącznik do uchwały RM nr 115/2016. 
Obywatelskich dr. A. Bodnara, w „sytuacji kiedy mamy ogólny kryzys mieszkaniowy dotyczący setek tysięcy osób, tego typu inicjatywy nie zawsze są otwarcie popierane. Wszak wiążą się z zaangażowaniem środków publicznych i gospodarowaniem «towarem rzadkim», jakim jest mieszkanie" [Wygnańska, 2015, s. 7]. Istniejące w chwili obecnej przeszkody odnoszące się do możliwości organizacyjnych gmin i istniejące rozwiązania prawne nie sprzyjają wdrażaniu metody housing-first przez administrację publiczną w jej działaniach na rzecz ograniczania zjawiska bezdomności. Jedyną alternatywą na rzecz upowszechniania tej metody wydaje się być w chwili obecnej udział organizacji pozarządowych i innych podmiotów spoza

\section{Literatura}

Allen M. (2016). „Quality Standards in Homeless Services, Housing Led Approaches and the Legacy of 'Less Eligibility'", European Journal of Homelessness, nr 6, s. 159-166.

Atherton I., McNaughton N.C. (2008). "Housing First as a means of addressing multiple needs and homelessness", European Journal of Homelessness, nr 2, s. 289-303.

Browarczyk Ł., Stenka R. (red.) (2012). Model. Gminny standard wychodzenia z bezdomności. Gdańsk: Pomorskie Forum na rzecz Wychodzenia z Bezdomności.

Busch-Geertsema V. (2016). Housing First. Synthesis Report. Peer Review in Social Protection and Social Exclusion. Belgium: European Commission, DG Employment, Social Affairs and Inclusion.

Dębski M. (2014). „Wybrane metody pracy z bezdomnymi", Nowa Praca Socjalna, nr 17, Warszawa: Centrum Rozwoju Zasobów Ludzkich.

FEANTSA (2011). Housing-led policy approaches: Social innovation to end homelessness in Europe. Brussels: FEANTSA, http://www.feantsa.org/ download/14_11_2011_hf_position_paper_final_ en2408443683520304907.pdf (dostęp: 31.08.2017).

Garapich M.P. (2016). London's Polish Borders: Transnationalizing Class and Ethnicity among Polish. Stuttgart: ibidem Press.

Goryńska-Bittner B. (2010). Diagnosis of a scale and nature of homelessness relating to Poles living in Europe. Barka Network, http://www.barkauk.org/wp-content/uploads/2010/07/Barbara_gorynska-report-1. doc (dostęp: 31.08.2017). sektora administracji publicznej, które przy finansowym wsparciu ze strony administracji podejmowałyby się realizacji programów opartych o formułę housing-first. Niemniej jednak, mimo wykazanych ograniczeń dla możliwości stosowania metody housing-first w Polsce, ponownie warto przytoczyć słowa A. Bodnara "Nie wolno się zrażać, tylko cierpliwie tłumaczyć, jaki jest sens takiego programu, w jakim zakresie komponuje się on w ogólną problematykę dostępności mieszkań dla osób najuboższych i wykluczonych, a przede wszystkim dlaczego bezdomni są grupą społeczną, której konieczne jest okazywanie szczególnego, i dedykowanego dla nich wyłącznie, wsparcia." [ibidem].

GUS (2015). Gospodarka mieszkaniowa w 2015 r. Warszawa: GUS, http://stat.gov.pl/obszary-tematyczne/ infrastruktura-komunalna-nieruchomosci/nieruchomosci-budynki-infrastruktura-komunalna/gospodarka-mieszkaniowa-w-2015-r-,7,11.html (dostęp: 31. 08.2017).

HWCF (2015). Global Homelessness Statistics, Homeless World Cup Foundation, https://www.homelessworldcup.org/homelessness-statistics/ (dostęp: 31.08.2017).

Jabłecka B. (2012). Dostęp do mieszkalnictwa i bezdomność migrantów W Anglii. Badania, Ekspertyzy, Rekomendacje. Warszawa: Instytut Spraw Publicznych, http://www.isp.org.pl/uploads/pdf/750397215. pdf (dostęp: 31.08.2017).

Kenna P., Benjaminsen L., Busch-Geertsema V., Nasarre-Aznar S. (red.) (2016). Pilot project - Promoting protection of the right to housing - Homelessness prevention in the context of evictions. VT/2013/056. Full report - final version. Brussels: European Commission.

Krajowy program przeciwdziałania ubóstwu i wykluczeniu społecznemu 2020. Nowy wymiar aktywnej integracji (2014). Przyjęty przez Radę Ministrów uchwałą nr 165 z dnia 12 sierpnia 2014 r., https://www.mpips.gov.pl/bip/akty-prawne/programy/krajowy-program-przeciwdzialania-ubostwu-i-wykluczeniu-spolecznemu-2020-nowywymiar-aktywnej-integracji/ (dostęp: 01.10.2017).

Maslow A. (2007). Motywacja i osobowość. Warszawa: Wydawnictwo Naukowe PWN.

Mędrzycki R. (2013). „Bezdomność w świetle orzecznictwa sądów administracyjnych - wybrane aspekty", Kwartalnik Prawa Publicznego, nr 1, s. 185-198. 
Mędrzycki R. (2016a). „Nowe formy działania administracji publicznej i partnerów społecznych w zakresie przeciwdziałania bezdomności", w: I. Lipowicz (red.), Bezdomność. Problemy prawne, innowacyjne rozwiązania. Warszawa: Fundacja Didactics.

Mędrzycki R. (2016b). „Problem bezdomności W świetle wybranych regulacji prawych", Przegląd Legislacyjny, nr 4(98), s. 35-45.

Mieszkanie jako prawo człowieka (2015). Opracowanie na podstawie kursu internetowo-stacjonarnego "Na straży" - poziom centralny" prowadzonego przez Sieć Obywatelską Watch Dog we współpracy z Helsińską Fundacją Praw Człowieka i Stowarzyszeniem Homo Faber, http://www.czynajpierwmieszkanie.pl/mieszkanie-jako-prawo-czlowieka/ (dostęp: 31.08.2017).

Mikłaszewicz P. (2016). „Komentarz do art. 75”, w: M. Safjan, L. Bosek (red.), Konstytucja RP. Tom 1. Komentarz art. 1-86. Warszawa: C.H. Beck.

Moraczewska B. (2013). „Bezdomność. Definicja, problemy, rozwiązania obecne oraz historyczne odwołanie do ludzi luźnych", Studia Gdańskie. Wizje i rzeczywistość, t. 10, s. 113-128.

MRPiPS (2017). Mniej osób bezdomnych, 9 marca, http://www.mpips.gov.pl/aktualnosci-wszystkie/ pomoc-spoleczna/art,8681,mniej-osob-bezdomnych.html (dane: 31.08.2017).

NAEH (2016). Housing First, April 20, Washington, DC: National Alliance to End Homelessness, https://endhomelessness.org/resource/housing-first/ (dostęp: 31.08.2017).

Nitecki S. (2013). Komentarz do ustawy o pomocy społecznej wraz z przepisami wykonawczymi. Wrocław: Gaskor Sp. z o.o..

Olech P. (2013). Wykluczenie mieszkaniowe - zarys głównych problemów mieszkaniowych w Polsce oraz rekomendacje dla całościowej polityki społecznej. Ekspertyza przygotowana w ramach projektu "EAPN Polska - razem na rzecz Europy Socjalnej", http:// www.eapn.org.pl (dostęp: 31.08.2017).

Pleace N. (red.) (2016). Housing First Guide Europe. Brussels: FEANTSA.

Pleace N., Bretherton J. (2013). "The case for Housing First in the European Union: A Critical Evaluation

\section{Akty prawne i orzecznictwo}

Europejska Karta Społeczna sporządzona w Turynie 18 października 1961 r., Dz.U. z 1999 r. nr 8 poz. 67. Karta Praw Podstawowych Unii Europejskiej, Dz.Urz. UE C 303 z dnia 14 grudnia 2007 r., s. 1 ze sprost. Konstytucja RP z dnia 2 kwietnia 1997 r., Dz.U. nr 78 poz. 483 z późn. zm.

Międzynarodowy Pakt Praw Gospodarczych, Społecznych i Kulturalnych otwarty do podpisu w Nowym Jorku w 19 grudnia 1966 r., Dz.U. z 1977 r. nr 38 poz. 169. of Concerns about Effectiveness", European Journal of Homelessness, nr 7 (2), s. 21-42.

Płoszka A. (2015). „Bezdomność a prawa człowieka”, Państwo i Prawo, nr 8, s. 37-51.

Przymeński A. (2014). „Pomoc mieszkaniowa dla zmarginalizowanych ekonomicznie gospodarstw domowych jako element systemu zabezpieczenia w Polsce", Studia Ekonomiczne, nr 179, s. 237-248.

Schluz B. (2011a). „Zjawisko bezdomności we Francji", Zeszyty Naukowe Instytutu Socjologii, nr 3, s. 55-72. Schulz B. (2011b). „Przeciwdziałanie zjawisku bezdomności w Unii Europejskiej", Przegląd Europejski, nr 2, s. 7-21.

Schulz B. (2014). Zjawisko bezdomności w wybranych krajach Unii Europejskiej. Rzeszów: Wydawnictwo Uniwersytetu Rzeszowskiego.

Sierpowska I. (2010). "Socjalne aspekty prawa do mieszkania", Wrocławskie Studia Erazmiańskie, nr 4, s. 269-302.

Sierpowska I. (2016). „Sytuacja prawna osoby bezdomnej - aktywne czy pasywne formy wsparcia?", w: I. Lipowicz (red.), Bezdomność. Problemy prawne, innowacyjne rozwiq̨zania. Warszawa: Fundacja Didactics, S. $29-51$.

Skrzydło W. (2007). Konstytucja Rzeczypospolitej Polskiej: komentarz. Warszawa: Wolters Kluwer.

Tsemberis S.J. (2010). Housing First: The Pathways Model to End Homelessness for People with Mental IIIness and Addiction. Center City: Hazelden Press.

Wygnańska J. (2013). Model GSWB - opis rzeczywistości zastanej vs projekt przyszłej polityki społecznej. Ekspertyza merytoryczna Modelu Gminny Standard Wychodzenia z Bezdomności na zlecenie Caritas Diecezji Kieleckiej. Warszawa, http://kielce.caritas.pl/pdf/ ekspertyza-wygnanska.pdf (dostęp: 31.08.2017).

Wygnańska J. (red.) (2015). Najpierw mieszkanie. Materiały źródłowe. Warszawa Fundacja lus Medicinae,

Załącznik do uchwały RM nr 115/2016 z dnia 27 września 2016 r. w sprawie przyjęcia Narodowego Programu Mieszkaniowego, RM-111-119-16 (2016). http://mib.bip.gov.pl/budownictwo/programy.html (dostęp: 31.08.2017).

Opinia Komitetu Regionów - Europejska strategia dotycząca bezdomności 2014/C 271/07, Dz.Urz. UE z dnia 19 sierpnia 2014 r., C 271/36.

Powszechna Deklaracja Praw Człowieka i Obywatela przyjęta w dniu 10 grudnia 1948 r. przez Zgromadzenie Ogólne Organizacji Narodów Zjednoczonych. Ratyfikowana przez Polskę 9 października 1968 r., Dz.U. z 1969 r. nr 25 poz. 187.

Rozporządzenie Ministra Rodziny, Pracy i Polityki Społecznej z dnia 26 kwietnia 2018 r. w sprawie mieszkań chronionych, Dz.U. z 2018 r. poz. 822. 
Ustawa z 20 lipca 2017 r. o Krajowym Zasobie Nieruchomości, Dz.U. z 2017 r. poz. 1529.

Ustawa z 21 czerwca 2001 r. o ochronie praw lokatorów, mieszkaniowym zasobie gminy i o zmianie Kodeksu cywilnego, t.j. Dz. U. z 2016 r. poz. 1610 z późn. zm.
Ustawa z dnia 12 marca 2004 r. o pomocy społecznej, t.j. Dz.U. z 2017 r. poz. 1769 z późn. zm.

Wyrok TK z 20 kwietnia 2005 r., K 42/02, OTK-A 2005, Nr 4, poz. 38.

Wyrok TK z 9 marca 2003 r., SK 28/03, OTK-A 2003, $\mathrm{Nr}$ 7, poz. 74.

\section{Reducing homelessness on the basis of the example of Housing First program}

Summary: Homelessness is a large problem in Europe and it grows constantly. The aim of this article is therefore to bring its reader the idea of the program invented in the United States by Ph.D. S. Tsemberis, from the organization "Pathways to Housing", which main goal is to help homeless people with mental and physical problems and analysis of the possibility of its implementation in Poland. The program mentioned here is named Housing First and it gained a great popularity in Europe, where in 2011-2013 run a project named Housing First Europe in five big European cities: Amsterdam, Budapest, Copenhagen, Glasgow and Lisbon. The next aim of this article is comparison of housing-first philosophy and housing-led policy which is recommended in the EU. Despite of the fact that in Poland is not easy to run programs based on housing-first approach it is worth to explain its ideas and goals. Empirical, sociological and legaltheoretical methods were used in this article.

Keywords: homelessness, homeless people, housing-first programme, housing-led policy.

\section{Prawa autorskie i licencja / Copyright and License}

Artykuł opublikowano na licencji Creative Commons

Uznanie autorstwa - Użycie niekomercyjne - Bez utworów zależnych 3.0 Polska

http://creativecommons.org/licenses/by-nc-nd/3.0/pl/

This article is published under the terms of the Creative Commons

Attribution - NonCommercial - NoDerivs (CC BY-NG-ND 3.0) License

http://creativecommons.org/licenses/by-nc-nd/3.0/ 